\title{
MOLECULAR IDENTIFICATION OF E. COLI 0157:H7, VIRULENCE GENES AND QUINOLONE / FLUOROQUINOLONE RESISTANT GENES AMONG E. COLI ISOLATES FROM RETAILED MEAT IN IBADAN, SOUTHWEST NIGERIA
}

\author{
Deji-Agboola Anotu Mopelola ${ }^{1}$, Ayodele Oluwafunmilyo Abosede ${ }^{1,2}$, Faneye Adedayo Omotayo ${ }^{3}$, Akinduti \\ ${ }^{\mathrm{P}}$ aul Akinniyi ${ }^{4}$, Dada Veronica Kayinebi ${ }^{2}$ \\ ${ }^{1}$ Department of Medical Microbiology/Parasitology, Olabisi Onabanjo University, Ago-Iwoye, Nigeria \\ ${ }^{2}$ Department of Medical Microbiology, University College Hospital, Ibadan, Nigeria \\ ${ }^{3}$ Department of Virology, University of Ibadan, Ibadan, Nigeria \\ ${ }^{4}$ Microbiology Unit, Department of Biological Sciences, Covenant University, Otta, Nigeria \\ Corresponding e-mail address:mopelola.agboola@oouagoiwoye.edu.ng,mopeagboola@yahoo.co.uk
}

\begin{abstract}
Escherichia coli is classified based on their pathogenicity factor, the strain E. coli $\mathrm{O} 157: \mathrm{H} 7$ is implicated in diarrhoea leading to haemolytic uremic syndrome. Therefore this study identified $E$. coli O157:H7, virulence and quinolone/fluoroquinolone resistant genes in Escherichia coli isolates from meat.

Isolates of Escherichia coli from meat were identified by standard laboratory methods using Microbact GNB 12E (Oxoid), E. coli O157:H7 was identified by serotyping and the presence of virulence gene was determined by molecular methods. Antibiotic susceptibility of $E$. coli and quinolone/fluoroquinolone resistance (qnr) genes were determined using disc diffusion and molecular methods respectively.

Out of the 130 E. coli identified, $72(55.4 \%)$ were resistant to at least one or more of the antibiotics tested including quinolone/fluoroquinolones. E. coli $\mathrm{O} 157: \mathrm{H} 7$ were detected serologically 5 (3.9\%) and by the multiplex PCR $8(6.2 \%)$ out of which, 2 (25\%) carried eaeA, hly, rfbE and flich genes, $^{2}$

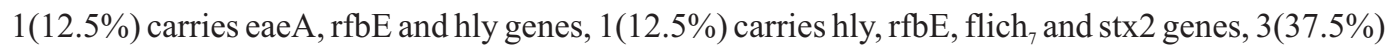
carries hly, rfbE and $\mathrm{flich}_{7}$ genes, 1 (12.5\%) carries $\mathrm{rfbE}$ and hly genes while none of the isolates have stx1 genes. Quinolone resistant genes (qnr) was harboured by $41(56.9 \%)$ of which $5(3.9 \%)$ and $36(27.7 \%)$ isolates carried qnrA and qnrB, respectively. Only $2(50 \%)$ of the $E$. coli $\mathrm{O} 157: \mathrm{H} 7$ harbour qnrB, no qnrA was detected.

The E. coli isolated from meat carries virulence and qnr resistance gene which could be potential vehicles for spread of multi-drug resistant to humans.
\end{abstract}

Keywords: E. coli $\mathrm{O} 157: \mathrm{H} 7$, Quinolone resistant genes, virulence gene

Accepted Date: $20^{\text {th }}$ Dec., 2019

\section{INTRODUCTION}

\section{Background}

Escherichia coli is a member of the family Enterobacteriaceae found in the lower intestines of warm-blooded animals and birds although most strains of the E. coli are non-pathogenic, some can cause a variety of intestinal and extra-intestinal infections in men, animals, and poultry (Todar,
2007). E. coli strains have been classified into different pathogenicity groups, based on their virulence properties (Nataro \& Kaper, 1998). Many produce a variety of potent toxins, including Shigalike toxins (Stx) (Wang et al., 2002). The Shiga toxin-producing $E$. coli (STEC) isolates express virulence in humans by this toxin (Nataro \& Kaper, 1998).

The most recognized representative pathotype of 
STEC is the Enterohemorrhagic E. coli (EHEC) strain O157:H7 (Caprioli et al., 2005; Newell \& Ragione, 2018) which causes diarrhea, haemorrhagic colitis, and haemolytic uremic syndrome in humans (García et al., 2010). The E. coli O157:H7 have been associated with food and water borne infections. Pathogen has been isolated from outbreaks of foodborne infections involving comsumption of beef and beef products (Sarimehmetoglu et al., 2009; Jeshveen, 2012). The strain is identified by the presence of one or two these virulence genes $\mathrm{rfbE}$ (O157 antigen), eae (intimin), stx1 (Shiga toxin 1), stx2 (Shiga toxin 2), hlyA (hemolysin) and fliCh7 (flagellar antigen) (Nataro \& Kaper, 1998; Sarimehmetoglu et al., 2009; Jeshveen, 2012).

Quinolones are synthetic antimicrobial agents with broad antibacterial spectrum and very potent activity against Enterobacteriaceae including $E$. coli (Chen et al., 2012). E. coli is increasingly becoming more resistant to these antibiotics and are involved in transmission of antibiotic-resistance genes to other Enterobacteriaceae in the environment (Hooper \& Jacoby, 2015; Laarem et al., 2017).Quinolones have long been used as one of the antimicrobial agents of choice for the treatment of various Gram-negative infections both in human and in veterinary medicine ostensibly increasing the rate of resistant isolates all over the world (Andriole, 2005; Caruso et al., 2018). Inappropriate, unnecessary and inevitable administrations of these antibiotics in human and food animals over time have resulted in the development and spread of resistant bacteria to animals, humans and the environment via food, water, direct animal contact, and other pathways (Gorbach, 2001; Rezazadeh et al., 2016) thus limiting treatment options.

The rise in quinolone resistance threatens the clinical utility of this important drug which acts by converting their targets, gyrase and topoisomerase $\mathrm{IV}$, into toxic enzymes that fragment the bacterial chromosome (Aldred et al., 2014). Quinolone resistance in Enterobacteriaceae results mainly from mutations in type II DNA topoisomerase genes and/or changes in the expression of outer membrane and efflux pumps. Plasmid-mediated resistance mechanisms also play a significant role in fluoroquinolone resistance, and is mediated by the genes (qnr) encoding proteins that belong to the pentapeptide repeat family and protect DNA gyrase and topoisomerase IV against quinolone compounds (Wang et al., 2008).

The three major groups of qnr determinants are qnrA, qnrB, and qnrS have been identified (Kim et al., 2009, Rezazadeh et al., 2016). The first plasmid-mediated quinolone-resistance gene (qnrA) was identified in a clinical strain of Klebsiella pneumoniae isolated in Alabama in 1998 (Mammeri, 2005). The other two determinants of qnr (qnrB and qnrS) have subsequently been observed in other enterobacteria species including E. coli, Enterobacter spp., Salmonella spp., and Klebsiella pneumoniae (Andres, 2013).

Much reported work in Nigeria had involved conventional identification of $E$. coli $\mathrm{O} 157: \mathrm{H} 7$ from different sources (Olorunshola et al., 2000; Itelima \& Agina, 2011). This study therefore aimed at molecular identification of E. coli $\mathrm{O} 157: \mathrm{H} 7$ isolate from retailed meat samples in Ibadan, Nigeria, study of its virulence and quinolone/fluoroquinolone resistant genes.

\section{Materials and Methods \\ Isolates used for the study:}

The identified $E$. coli isolated from retailed meat an earlier study (Ayodele et al., 2019) was reactivated by sub-culturing on MacConkey agar and Sorbitol MacConkey agar (Oxoid, UK), incubated at $37^{\circ} \mathrm{C}$ for 18-24 hours in the incubator (Gulfex Medical and Scientific, England). The isolates were reconfirmed biochemically using Microbat $12 \mathrm{E}$ identification kit (Oxoid, UK) as described in the Manufacture's manual. Serological identification was carried out by agglutination method using Remel Wellcolex E. coli O157:H7 kit (Remel Europe Ltd, Kent UK) following manufacturer's instruction while PCR method was used for molecular identification of the E. coli $\mathrm{O} 157: \mathrm{H} 7$ isolate (Firoozeh et al., 2014).

\section{Antimicrobial Susceptibility of $\boldsymbol{E}$. coli}

The confirmed E. coli was inoculated on MuellerHinton agar (OXOID, UK) and antibiotic disks (Ampicillin, Amoxicillin/Clavulanic acid, Gentamicin, Cefuroxime, Ceftazidime, Meropenem Nalidixic acid, Ciprofloxacin, Pefloxacin, Norfloxacin and Levofloxacin) disc 
(OXOID, UK) were placed using Kirby-Bauer disc diffusion method according to the Clinical Laboratory Standards Institute guidelines (CLSI, 2013). E. coli ATCC 25922 was used as control. The zones of clearing around the disc were measured and obtained data compared and interpreted as sensitive, resistant or intermediate (CLSI, 2013).

\section{DNA extraction and qnr genes detection}

Total DNA was extracted from the confirmed $E$. coli isolates using Bacteria DNA extraction kit (Jena Bioscience, Germany) following the manufacturer's instructions. The DNA was used to identify E. coli O157:H7 and screened for quinolone/fluoroquinolone resistance genes (qnrA and qnrB) using primers in Table 1 and 2 respectively, as described by Firoozeh et al., (2014). The amplification was carried out by adding $5 \mu \mathrm{L}$ of the of DNA sample to multiplex PCR reaction master mix primers for quinolone and fluoroquinolone resistance genes containing a premix of PCR buffer, Magnesium chloride, dNTPs, and Taq polymerase enzyme in optimized concentrations (Jena Bioscience, Germany) to obtain a $25 \mu \mathrm{L}$ reaction mix. The PCR reaction mixture was put in the Thermal cycler (Master Cycler Gradient Eppendorf, Hamburg, Germany) programmed at $95^{\circ} \mathrm{C}$ for 5 minutes to activate the Taq polymerase enzyme followed by 35 cycles of denaturation of the double-stranded DNA at $95^{\circ} \mathrm{C}$ for 45 seconds, primer annealing at $51^{\circ} \mathrm{C}$ for 45 seconds, elongation at $72^{\circ} \mathrm{C}$ for 45 seconds and final extension at $72^{\circ} \mathrm{C}$ for 7 minutes. The electrophoresis of amplified products was performed as described by Lee et al., (2012) using $2 \%$ agarose gel, stained with ethidium bromide for 15 minutes and visualized under the ultraviolet light using the Trans-illuminator (Bio-Rad, Italy).

\section{Results}

All the 130 isolates from retailed meat were confirmed as E. coli biochemically, the serotyping identified only $5(3.9 \%)$ as E. coli $\mathrm{O} 157: \mathrm{H} 7$ whereas, the multiplex PCR detected $8(6.2 \%)$. Out of the eight (8) E. coli O157:H7 identified by multiplex PCR assay, all $8(100 \%)$ carried $h l y$ and $r f b E$ genes, $6(75 \%)$ carries $f l i C_{h}, 3(37.5 \%)$ carries eaeA while only1 (12.5\%) stx2. None of the isolates have stxlgene (Figure 1).

Antibiotic susceptibility test revealed that 72
$(55.4 \%)$ out of $130 \mathrm{E}$. coli were resistant to at least one quinolone/fluoroquinolone, $41 \quad(56.9 \%)$ harboured qnr genes, out of which $5(3.9 \%)$ where qnrA and $36(27.7 \%$ ) qnrB, (Figure 2 and 3 ). The $E$. coli $\mathrm{O} 157: \mathrm{H} 74(50 \%)$ isolated were resistant to one or more quinolone/fluoroquinolone. qnrB gene was detected in only $2(25 \%)$ of the $E$. coli $\mathrm{O} 157: \mathrm{H} 7$ while qnrA gene was absent (Figure 4 and 5).

\section{Discussion}

The identification of Escherichia coli $\mathrm{O} 157: \mathrm{H} 7$ in this study is in line with various reports of $E$. coli O157:H7 in meat (Hiko et al., 2008; Olatoye, 2010; Hessain, 2015). The strain has been isolated from the intestines of healthy cattle, deer, goats, and sheep (Newell \& La Ragione, 2018). Cattle are probably the most important source of E. coli O157:H7 infections in humans, outbreaks of which have been associated directly with consumption of processed meat product from cattle and other ruminant animals (Sarimehmetoglu et al., 2009; WHO, 2018).

The identified E. coli $\mathrm{O} 157: \mathrm{H} 7$ strains carried at least two of the virulence genes tested. The carriage of two more virulence genes by E. coli O157:H7 have been reported by similar studies (Hessain et al., 2015; Oloyede et al., 2016; Ayaz, et al., 2016). The most common genes identified in this study are $h l y A, r f b E$ and $f l i C_{h 7}$. E. coli O157:H7 form Shiga toxin encoded by stx 1 and stx 2 genes which are the A-B type toxin that inhibits protein synthesis and causes haemorrhagic colitis and haemolytic-uremic syndrome (Jeshveen et al., 2012; Javadi et al., 2016). Only stx2 gene was observed in this study. The production of $S t \times 2$ by strains of $E$. coli O157:H7 have been associated with severe human disease with an increased risk of systemic complications (Boerlin et al., 1999; García et al., 2010). Stx 2 gene is frequently detected in strains isolated from patients with haemolytic-uremic syndrome and uncomplicated diarrhoea (Friedrich etal., 2002).

All the virulence genes identified in this study are associated with severity of infection caused by the E. coli O157:H7. Haemolysin is encoded by hlyA gene which is found in almost all $\mathrm{O} 157$ strains, $\mathrm{rfbE}$ gene expresses $\mathrm{O} 157$ antigen (Jeshveen et al., 2012). The flagella antigen encoded by $f_{l i} C_{h 7}$ gene plays a vital role in bacterial movement and 
distribution in host intestine and tissues (Javadi et al., 2016). Furthermore the eaeA gene is known to encode intimin, which is responsible for adherence of this pathogen to the intestinal lining and causing human illnesses (Sarimehmetoglu et al., 2009).

Quinolone/fluoroquinolone resistant genes (qnr) were detected in majority of the isolates; qnrB $27.7 \%$ was more predominant than qnrA $3.9 \%$. qnrA and qnrB genes have been reported in animals and human in similar studies (Chen et al., 2012; Caruso et al., 2018). These resistant genes carried by bacteria can be transferred from animals to human through the food chain. The detection of quinolone/fluoroquinolone-resistant $E$. coli among the isolates from meat is of public health significance because the resistant genes may be transferred to consumers who will subsequently develop resistance to therapeutic agents.

\section{Conclusion}

This study established the existence of E. coli O157:H7 strains that possessed at least two of the virulence $\left(f l i C_{h 7} r f b E\right.$, eaeA, hly and stx2) genes which could predispose the consumer of the meat to food borne infection. The presence of quinolone/fluoroquinolone resistant genes (qnrA and $\mathrm{qnrB}$ ) in the isolates makes them potential vehicles for spread of quinolone/fluoroquinolone drug resistance to humans.

Transparency declarations: None to declare Authors' contributions

AM conceived, designed supervised the experiment and proofread the manuscript; OA designed, collected samples, performed the experiment, drafted the manuscript, $\mathrm{AO}$ assisted in molecular work and analysis, PA assisted in experimental design and manuscript drafting, VK assisted in experimental aspect. All authors read and approved the final manuscript.

Ethics approval and consent to participate: Not applicable

Competing interests: The authors declare that they have no competing interest

Table 1: Primers and primer sequences for the identification of $E$. coli O157: $\mathrm{H} 7$

\begin{tabular}{|c|c|c|c|c|}
\hline Primers & Sequences $\left(5^{\prime}-3^{\prime}\right)$ & $\begin{array}{l}\text { Target } \\
\text { gene }\end{array}$ & $\begin{array}{l}\text { Amplicon } \\
\text { size (bp) }\end{array}$ & Reference \\
\hline FLICH7-F & GCGCTGTCGAGTTCTATCGAGC & $\mathrm{fliC}_{\mathrm{h} 7}$ & 625 & $\begin{array}{l}\text { Sarimehmetoglu } \\
\text { et al.. } 2009\end{array}$ \\
\hline FLICH7-R & CAACGGTGACTTTATCGCCATTCC & & & \\
\hline rfbE-F & CAGGTGAAGGTGGAATGGTTGTC & $\mathrm{rfbE}$ & 296 & $\begin{array}{l}\text { Jeshveen et al., } \\
2012\end{array}$ \\
\hline rfbE-R & TTAGAATTGAGACCATCCAATAAG & & & \\
\hline SLT1-F & TGTAACTGGAAAGGTGGAGTATACA & stx $_{1}$ & 210 & $\begin{array}{l}\text { Sarimehme toglu } \\
\text { et al., } 2009\end{array}$ \\
\hline SLT1-R & GCTATTCTGAGTCAACGAAAAATAAC & & & \\
\hline SLT11-F & GTTTTTCTTCGGTATCCTATTCC & $\operatorname{stx}_{2}$ & 484 & $\begin{array}{l}\text { Sarimehmetoglu } \\
\text { et al., } 2009\end{array}$ \\
\hline SLT11-R & GATGCATCTCTGGTCATTGTATTAC & & & \\
\hline AE22 & ATTACCATCCACACAGACGGT & eaeA & 397 & $\begin{array}{l}\text { Sarimehmetoglu } \\
\text { et al., } 2009\end{array}$ \\
\hline AE20-2 & ACAGCGTGGTTGGATCAACCT & & & \\
\hline MFS 1-F & ACGATGTGGTTTATTCTGGA & Hly & 166 & $\begin{array}{l}\text { Sarimehme toglu } \\
\text { et al., } 2009\end{array}$ \\
\hline MFS1-R & CTTCACGTCACCATACATAT & & & \\
\hline
\end{tabular}


Table 2: The primers and primer sequences for quinolone and fluoroquinolone resistance genes

\begin{tabular}{llll}
\hline Primers & Sequences (5-- -3) & $\begin{array}{l}\text { Target } \\
\text { gene }\end{array}$ & $\begin{array}{l}\text { Amplicon } \\
\text { size (bp) }\end{array}$ \\
\hline qnrA F & ATTTCTCACGCCAGGATTTG & qnrA & 516 \\
qnrA R & GATCGGCAAAGGTTAGGTCA & & \\
qnrB F & GATCGTGAAAGCCAGAAAGG & qnrB & 469 \\
qnrB R & ACGATGCCTGGTAGTTGTCC & & \\
\hline
\end{tabular}

Firoozeh et al., (2014)

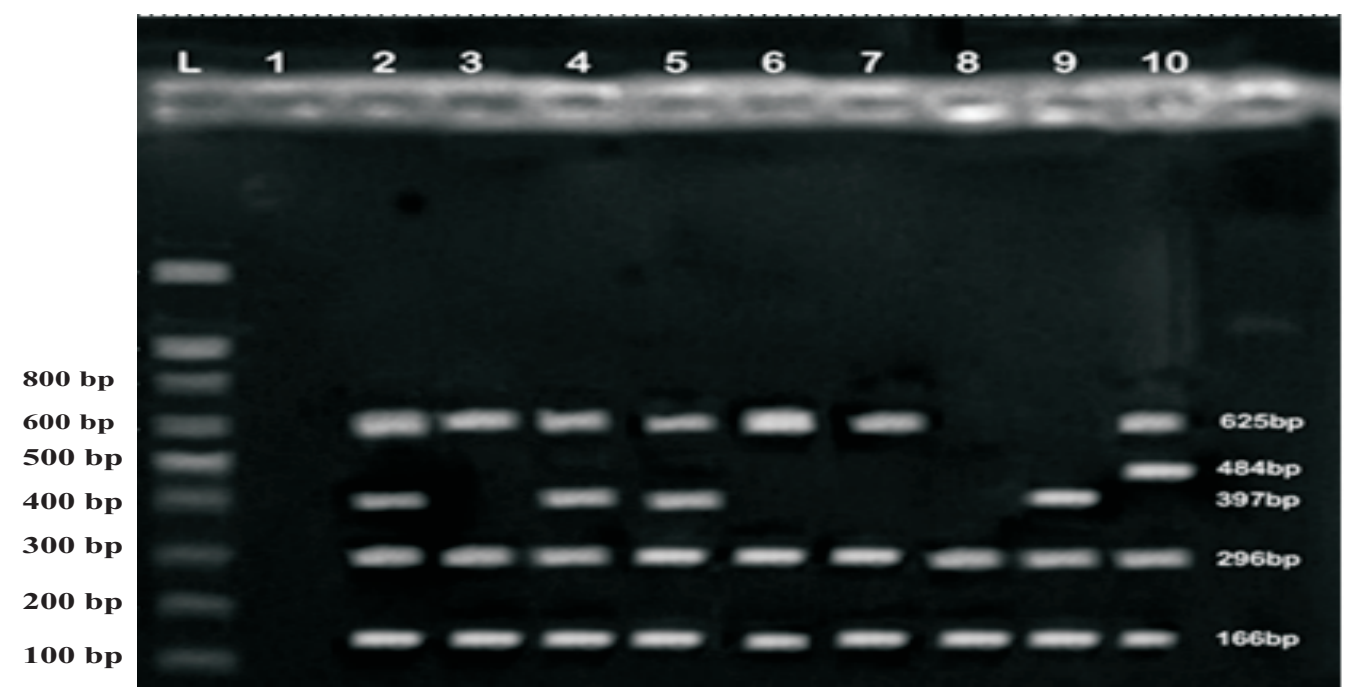

Figure 1: Gel electrophoresis of amplicons of $f l i C_{h 7}$ (625bp), stx1 (210bp), stx2 (484bp), eaeA (397bp), hly (166bp) and $r f b E$ (296bp) genes of $E$. coli $0157: \mathrm{H} 7$ in $E$. coli isolates. Lane L: DNA ladder (100 bp), lane 1: negative control, lane 2: positive control, lanes 3 - 11: amplicons from the isolates. Lanes 3, 6, 7: hly, rfbE, fliC $h_{h 7}$ genes; lanes 4, 5: hly, rfbE, eaeA, fliC ${ }_{h 7}$ genes; lanes 8: $h l y, r f b E$ genes; lane 9: $h l y, r f b E$, eae $A$; lane 10: $h l y, r f b E$, stx2, fliC $C_{h}$ genes.

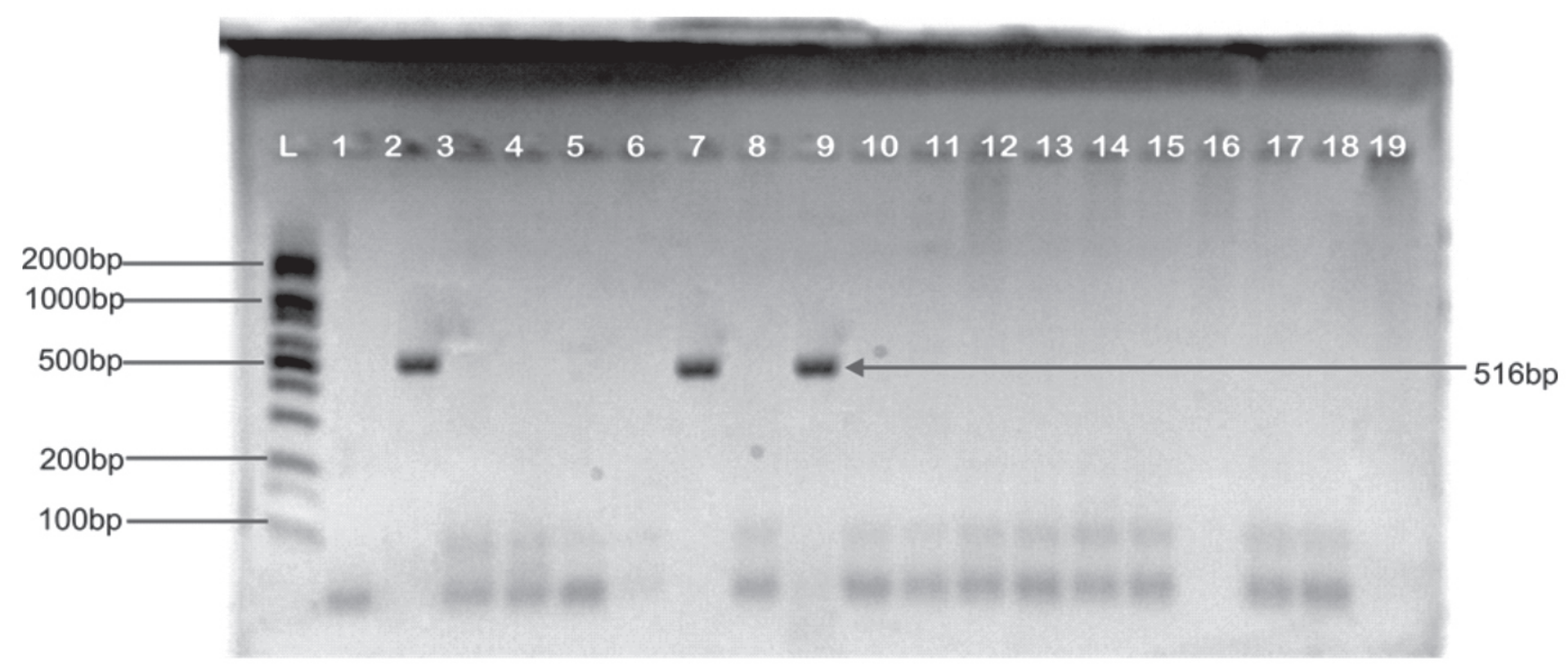

Figure 2: Gel electrophoresis of amplicons showing the presence of quinolone and fluoroquinolone resistance genes (qnrA) in E. coli isolates. Lane L: DNA ladder (100 bp), lane 1: negative control, lane 2: positive control and lanes 3 -19: amplicons from the isolates. Lanes 7 and 9 have qnrA genes 


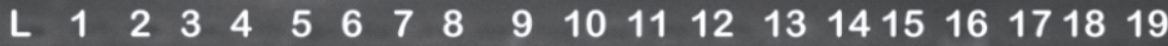

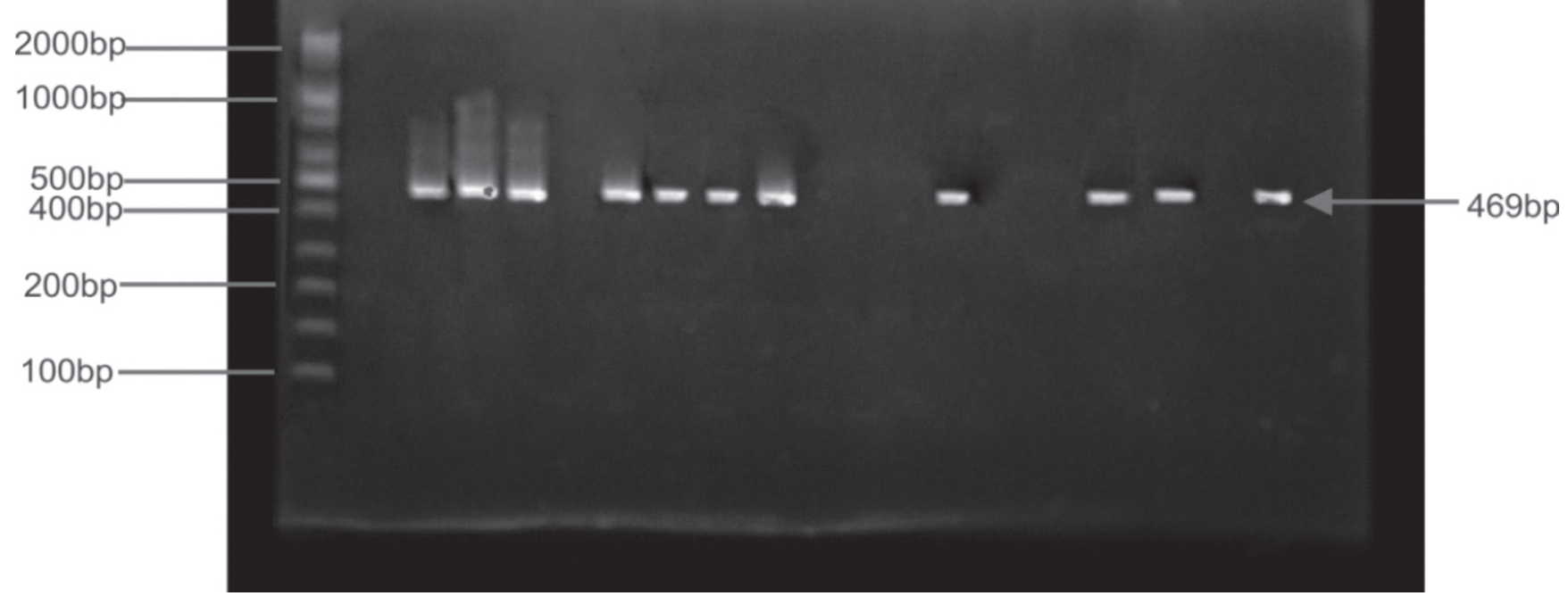

Figure 3: Gel electrophoresis of amplicons showing the presence of quinolone and fluoroquinolone resistance genes (qnrB) in $E$. coli isolates. Lane L: DNA ladder (100 bp), lane 1: negative control, lane 2: positive control and lanes 3 - 19: amplicons from the isolates

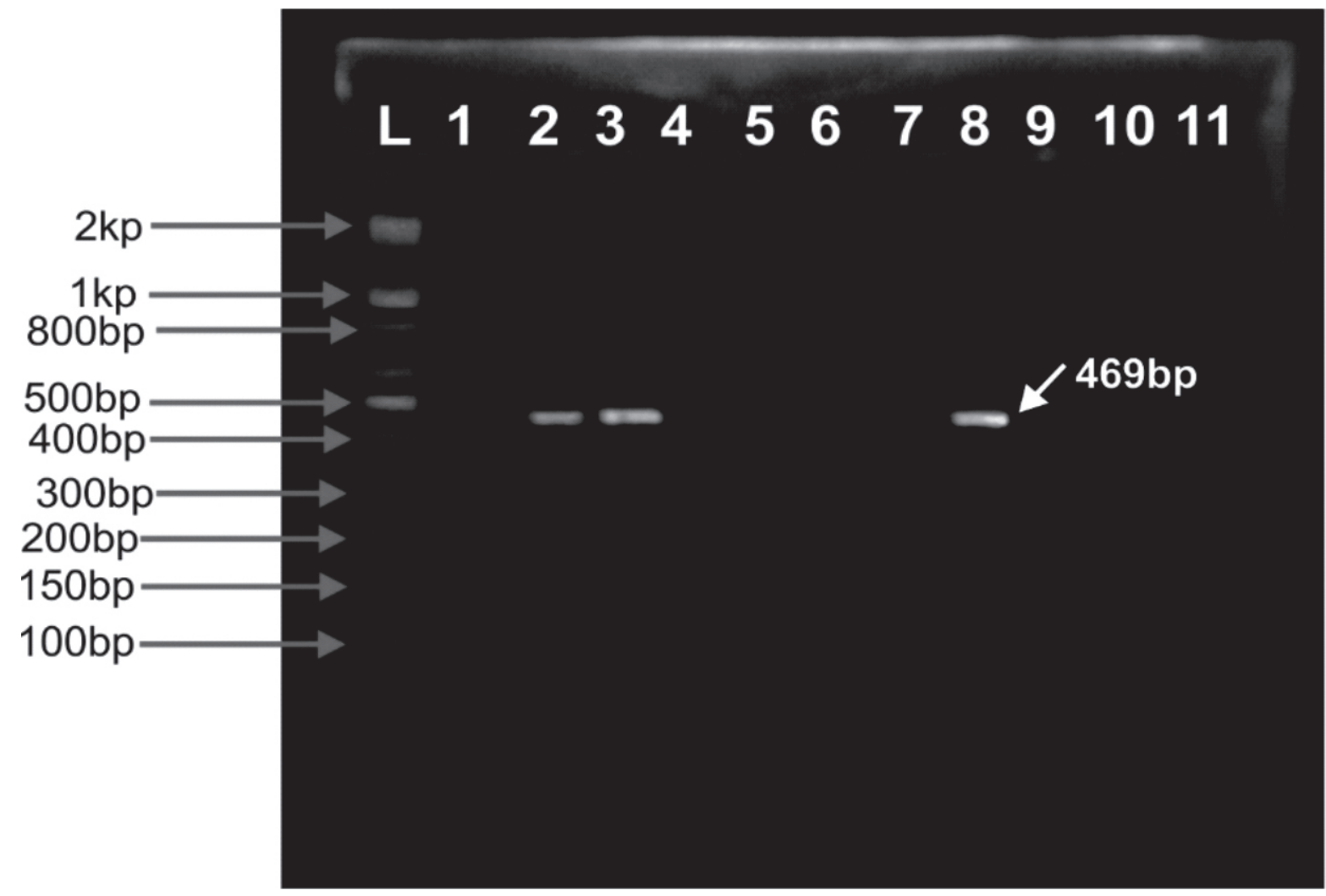

Figure 4: Gel electrophoresis of amplicons showing the presence of quinolone and fluoroquinolone resistance genes (qnrB) in $E$. coli 0157:H7 isolates. Lane L: DNA ladder (100 bp), lane 1: negative control, lane 2: positive control and lanes $3-11$ : amplicons from the isolates 


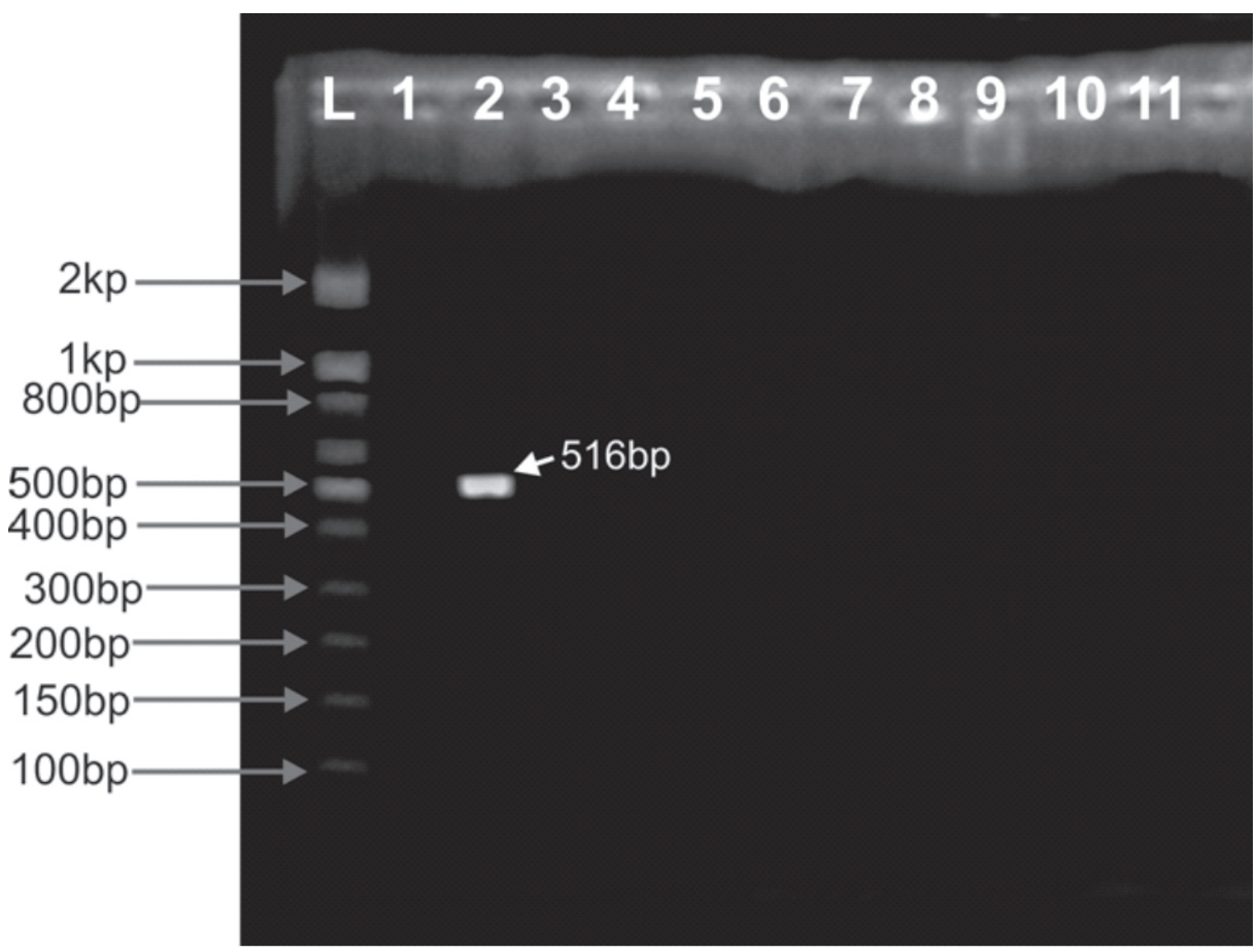

Figure 5: Gel electrophoresis of amplicons showing the absence of quinolone and fluoroquinolone resistance genes (qnrA) in $E$. coli O157:H7 isolates. Lane L: DNA ladder (100 bp), lane 1: negative control, lane 2: positive control and lanes 3 - 11: amplicons from the isolates

\section{References}

Aldred, K. J, Kerns, R. J.\& Osheroff, N. (2014). Mechanism of Quinolone Action and Resistance. Biochemistry, 53, 1565-1574 dx.doi.org/10.1021/bi5000564.

Andres, P., Lucero, C., Soler-Bistue,' A., Guerriero, L., Albornoz, E., Tran, T.\& Zorreguieta, A., Galas, M., Corso, A., Tolmasky, M. E.\& Petroni, A. (2013). Differential distribution of plasmid-mediated quinolone resistance genes in clinical enterobacteria with unusual phenotypes of quinolone susceptibility from Argentina. Antimicrobial Agents and Chemotherapy. 57(6), 2467-2475. doi: 10.1128/AAC.0161512.

Andriole, V. T. (2005). "The quinolones: past, present, and future," Clinical Infectious Diseases. 41(2), S113-S119.

Ayaz, N. M., Cufaoglu, G., Ormeci, E. \& Oz, B. (2016). Presence of Staphylococcus aureus and Shiga Toxigenic Escherichia coli O157:H7 in Raw Meat in Agri, Turkey. International Journal of Enteric Pathogen, 4(3), e36523.

Ayodele, O. A., Deji-Agboola, A. M., Akinduti, P. A. \& Faneye, A. O. (2019): Phylo-diversity of prevalent human $E$. coli $\mathrm{O} 157: \mathrm{H} 7$ with strains from retailed meat and fish in selected markets in Ibadan Nigeria, Journal of Immunoassay and I $m$ m un o che mistry. d o i : 10.1080/15321819.2019.1694942

Boerlin P., McEwen S.A., Boerlin-Petzold F., Wilson J.B., Johnson R.P.\& Gyles C.L. (1999). Associations between virulence factors of Shiga toxin-producing Escherichia coli and disease in humans. Journal of Clinical Microbiology, 37, 497-503.)

Caprioli. A., Morabito. S., Brugère H., \& Oswald, E. (2005). Enterohaemorrhagic Escherichia coli: emerging issues on virulence and modes of transmission. Veterinary Research, 36: 289-311 
Caruso, G., Giammanco A., Cardamone C., Oliveri G., Mascarella C., Capra G. \& Fasciana T. (2018). Extra-Intestinal FluoroquinoloneResistant Escherichia coli Strains Isolated from Meat. BioMed Research International, Article ID 8714975, 7 pages. Retrieved from .

Chen, X., Zhang, W., Pan, W., Yin, J., Pan, Z., Gao, S. \& Jiao X. (2012). Prevalence of qnr, aac (6')Ib-cr, qepA, and oqxAB in Escherichia coli Isolates from Humans, Animals, and the Environment. Antimicrobial Agents and Chemotherapy, 56 (6), 3423-3427.

CLSI (2013). Performance Standards for Antimicrobial Susceptibility Testing, $23^{\text {rd }}$ ed. CLSI Supplement M100-S23, 33(1). Wayne, PA: Clinical and Laboratory Standards Institute.

Firoozeh, F., Zibaei, M. \& Soleimani-As, Y. (2014). Detection of plasmid-mediated $q n r$ genes among the quinolone-resistant Escherichia coli isolates in Iran. Journal of Infectious Diseases in Developing Countries, 8(7), 818-822.

Friedrich A.W., Bielaszewska M., Zhang W.L., Pulz M., Kuczius T., Ammon A.\& Karch H. (2002) Escherichia coli harboring Shiga toxin 2 gene variants: frequency and association with clinical symptoms, Journal of Infectious Diseases, 185(1), 74-84.

García, A., Fox, J. G. \& Besser,T. E. (2010). Zoonotic Enterohemorrhagic Escherichia coli: A One Health Perspective ILAR Journal, 51(3), 221-232

Gorbach, S.L. Antimicrobial use in animal feedtime to stop. (2001) New England Journal of Medicine, 345, 1202-1203.

Hessain, A. M., Al-Arfaj, A. A., Zakri, A. M., ElJakee, J. K., Al-Zogibi, O. G., Hemeg, H.A.\& Saudi, I. M. I. (2015). Molecular characterization of Escherichia coli O157:H7 recovered from meat and meat products relevant to human health in Riyadh, SaudiArabia. Journal of Biosciences, 22, 725729.

Hiko, A., Asrat, D.\& Zewde, G. (2008): Occurrence of Escherichia coli $\mathrm{O} 157: \mathrm{H} 7$ in retail raw meat products in Ethiopia. Journal of Infectious diseases in Developing Countries, 5: 389-393.

Hooper D. C \& Jacoby G. A. (2015). Mechanisms of drug resistance: quinolone resistance. Annals of New York Academy of Science, 17:
12830.

Itelima, J. U., \& Agina S. E. (2011). The

Occurrence of Escherichia coli $\mathrm{O} 157: \mathrm{H} 7$ in

Market and

Abattoir Meat in Plateau State, Nigeria.

Global Journal of Environmental Sciences, 10

(1\&2), 47-55

Javadi, M., Oloomi, M., \& Bouzari M. S. (2016). Genotype Cluster Analysis in Pathogenic Escherichia coli Isolates Producing Different CDT Types. Journal of Pathogens, Article ID 9237127, 8 pages Retrieved from, on 28, February 2019

Jeshveen, S. S., Chai, L. C., Pui, C. F. \& Son, R. (2012). Optimization of multiplex PCR conditions for rapid detection of Escherichia coli $\mathrm{O} 157: \mathrm{H} 7$ virulence genes. International Food Research Journal 19(2), 461-466.

Kim, H. B., Park, C. H., Kim, C. J., Kim, E-C., Jacoby, G. A., \&Hooper, D. C. (2009). Prevalence of plasmid-mediated quinolone resistance determinants over a 9-year period. Antimicrobial Agents and Chemotherapy, 53(2):639-645.

Laarem, M., Barguigua, A., Nayme, K., Akila, A., Zerouali, K., El Mdaghri, N. \& Timinouni, M. (2017). Occurrence of plasmid-mediated quinolone resistance and virulence genes in avian Escherichia coli isolates from Algeria. Journal of Infectious diseases in Developing Countries, 11(2), 143-151.

Lee, P.Y., Costumbrado, J., Hsu, C.Y. \&Kim, Y.H. (2012).Agarose Gel Electrophoresis for the Separation of DNA Fragments. Journal of Visual Experiment. (62): e3923, doi:10.3791/3923.

Mammeri, H., Van De Loo, M., Poirel, L., Martinez- Martinez, L. \& Nordmann, P. (2005). Emergence of plasmid-mediated quinolone resistance in Escherichia coli in Europe. Antimicrobial Agents Chemotherapy, 49(1),7176.

Nataro, J. P., and Kaper, J. B. (1998). Diarrheagenic Escherichia coli. Clinical Microbiology Reviews, 11, 142-201.

Newell D. G. \& La Ragione, R. M. (2018). Enterohaemorrhagic and other Shiga toxinproducing Escherichia coli (STEC): Where are we now regarding diagnostics and control strategies? Transbound Emerging Diseases. 
65 (Suppl. 1), 49-71. DOI:

$10.1111 /$ tbed.12789

Olatoye, I. O. (2010). The incidence and antibiotics susceptibility of Escherichia coliO157:H7 from beef in Ibadan Municipal, Nigeria. African Journal of Biotechechnology, 9(8), 1196-1199.

Olorunshola, I. D., Smith, S. I., Coker, A. O.

(2000). Prevalence of EHEC O157:H7 in patients with

diarrhoea in Lagos, Nigeria. Acta pathologica, microbiologica et immunologica Scandinavian, 108(11), 761-763.

Oloyede, A. R., Afolabi, O. R. \& Olalowo, O. S (2016). Molecular detection of virulence genes and antibiotic resistance patterns of Escherichia coli $\mathrm{O} 157: \mathrm{H} 7$ isolated from raw beef sold in Abeokuta, South-West Nigeria. Nigerian Journal of Biotechnology, 31, 15-21.

Rezazadeh, M., Baghchesaraei, H. \& Peymani, A. (2016). Plasmid-Mediated QuinoloneResistance (qnr) Genes in Clinical Isolates of Escherichia coli collected from Several Hospitals of Qazvin and Zanjan Provinces, Iran. Osong Public Health and Research Perspectives, 7(5), 307-312.

Sarimehmetoglu, B., Aksoy, M. H., Ayaz, N. D.,
Ayaz, Y., Kuplulu, O. \& Kaplan, Y. Z. (2009). Detection of Escherichia coli O157:H7 in ground beef using immunomagnetic separation and multiplex PCR. Food Control, 20, 357-361.

Todar K. Pathogenic E. coli Online Textbook for Bacteriology. (2007). Retrieved from . 28, February 2019

Wang, G., Clark, C. G. \& Rodgers, F. G. (2002).

Detection in Escherichia coli of the Genes

Encoding the Major Virulence Factors, the Genes Defining the O157:H7 Serotype, and Components of the Type 2 Shiga Toxin Family by Multiplex PCR. Journal of Clinical Microbiology, 40 (10), 3613-3619. DOI: 10.1128/JCM.40.10.3613-3619.2002

Wang, A., Yang, Y., Lu, Q., Wang, Y., Chen, Y., Deng, L., Ding, H., Deng, Q., Zhang, H., Wang, C., Liu, L., Xu X, Wang L \& Shen X. (2008). Presence of qnr gene in Escherichia coli and Klebsiella pneumoniae resistant to ciprofloxacin isolated from pediatric patients in China. BMC Infectious Diseases, 8, 68.

WHO (2018). E. coli.https://www.who.int/newsroom/fact-sheets/detail/e-coli. Retrieved 28, February 2019 